\title{
AGi (ARTificial General INTELligenCe): Peluang Indonesia Melompat Jauh Ke DePAN
}

\author{
Johanes B. Bunyamin \\ Peneliti AGI, berlokasi di Bandung \\ johanbudibun@gmail.com
}

\begin{abstract}
Abstrak-AGI (Artificial General Intelligence) adalah kecerdasan buatan yang setara dengan kecerdasan manusia, sehingga semua pekerjaan intelektual manusia bisa digantikan oleh perangkat AGI. Nilai komersialnya akan sangat tinggi di masa yang akan datang. Devisa yang diperoleh dari ekspor perangkat AGI bisa mencapai 10 triliun dolar per tahun.

Indonesia memiliki peluang mengembangkan teknologi AGI dan mengkomersialkannya, sebab sampai saat ini belum ada satu ahli pun yang mengetahui cara kerja otak manusia secara lengkap yang bisa dijabarkan ke dalam algoritma A GI. Jadi, Indonesia tidak ketinggalan. Berdasarkan perkiraan paling optimis, AGI akan tercipta pada tahun 2029. Bila Indonesia menganggarkan dana untuk penelitian dan pengembangan AGI sebesar Rp 90 miliar total untuk 10 tahun, ada kemungkinan Indo nesia berhasil menciptakan AGI. Biaya ini relatif kecil sebab strateginya adalah memanfaatkan sebanyak mungkin teknologi yang sudah dipublikasikan baik berupa open source maupun API (Application Programming Interface), dan menjadwalkan eksperimen sesuai dengan penurunan harga perangkat keras.

Dalam makalah ini penulis mengusulkan Model Kecerdasan Berbasis Konsep atau CBIM (Concept Based Intelligence Model), yang dapat digunakan untuk menciptakan AGI. Model ini menggunakan pendekatan berdasarkan cara kerja otak manusia bukan hanya dari segi struktural otak melainkan juga pembelajaran dan perkembangannya secara evolusi. Secara teori, model ini masuk akal (plausible) karena bisa memberikan jawaban yang memuaskan terhadap masalah-masalah utama dalam menciptakan AGI. Namun, model ini hanya terbukti benar setelah dilakukan pengembangan. Karena kompleksitasnya dalam tingkat detail, diperkirakan butuh waktu 10 tahun untuk menyelesaikan pengembangannya, dimana targetnya adalah mendidik AGI sampai tingkat sarjana.

Keberhasilan pengembangan AGI memiliki nilai yang sangat strategis. Sebagaimana diilustrasikan dalam makalah ini, AGI bisa dimanfaatkan untuk mencerdaskan kehidupan bangsa, sesuai amanah UUD 45. Kemajuan akan mengalami percepatan di segala bidang termasuk di bidang ekonomi, kesehatan, pendidikan, budaya, sains, teknologi, dan militer, sehingga Indonesia akan menjadi negara termaju. Mengingat nilai strategisnya, sebaiknya pemerintah segera memulai proyek AGI.
\end{abstract}

Kata Kunci-AGI (Artificial General Intelligence), kecerdasan buatan, mencerdaskan kehidupan bangsa, strategi nasional

\section{Pendahuluan}

Sejak berdirinya AI (Artificial Intelligence) pada tahun 1956, cita-cita para pelopor AI adalah membuat komputer secerdas manusia. Sejak itu AI sudah berkembang luar biasa, namun hingga kini AI hanya cerdas dalam bidang yang spesifik (sempit), misalnya menjadi sopir, resepsionis, penjawab trivia, pemain catur, dsb. Karena itu, AI yang seperti ini disebut kercerdasan buatan sempit atau ANI (Artificial Narrow Intelligence). Sedangkan, AI yang memiliki kecerdasan lengkap manusia, seperti memahami bahasa manusia dan berpikir kreatif, hingga kini belum berhasil diciptakan. Untuk membedakan dengan ANI, AI yang memiliki kecerdasan lengkap manusia diberi istilah AGI (Artificial General Intelligence) atau HLAI (Human Level Artificial Intelligence). 
Nilai dari AGI sangatlah tinggi, karena AGI akan dapat menggantikan hampir semua pekerja kerah putih, yang pada dasarnya mengandalkan kemampuan intelektual. AGI bukanlah hanya perangkat yang akan membantu manusia, melainkan juga bisa menggantikan manusia. Semua pekerjaan profesional seperti insinyur, dokter, akuntan, dan pengacara bisa digantikan oleh AGI. Secara bisnis, satu unit komputer AGI bisa disewakan dengan harga 50.000 dolar US per tahun menggantikan seorang profesional. Jumlah unit yang disewakan bisa mencapai 200 juta unit dengan cara mengekspornya ke manca negara.

Kalau Indonesia berhasil menciptakan AGI, devisa yang diperoleh akan mencapai 10 triliun dolar US per tahun. Dalam segi ekonomi, Indonesia akan mengalami percepatan kemajuan, karena keuntungan dari ekspor AGI bisa diinvestasikan dalam pengembangan teknologi tinggi, yang nilai tambahnya sangat tinggi.

Dalam segi teknologi, Indonesia akan mengalami percepatan kemajuan karena kita bisa mempekerjakan AGI sebagai ilmuwan dan insinyur. Masalah-masalah yang tidak bisa atau belum terpecahkan oleh manusia akan terpecahkan oleh AGI, misalnya dalam mengatasi krisis energi. Mengapa AGI akan melebihi kemampuan manusia? Karena: (1) AGI yang dipekerjakan jumlahnya banyak sekali, misalnya: 100 juta unit, (2) AGI bisa berpikir lebih cepat tergantung dari daya komputer (computing power), (3) AGI bisa lebih cerdas karena bisa memiliki memori kerja (working storage) yang lebih besar, dan (4) AGI lebih bagus dalam kerja sama team karena AGI bisa dilengkapi dengan 'kepribadian' ideal seorang profesional yang kooperatif.

Tujuan dari penulisan makalah ini adalah:

- Memaparkan masalah-masalah dalam menciptakan AGI. Apakah yang sudah dilakukan para ahli untuk mengatasinya? Apakah yang bisa dimanfaatkan dari penelitian para ahli dan proyek-proyek AGI yang sedang berjalan?

- Mengusulkan sebuah model yang bisa dikembangkan menjadi perangkat AGI yang memiliki kemampuan intelektual setara sarjana dan bisa diterjunkan dalam pelbagai profesi.

- Memberikan ilustrasi pemanfaatan AGI dalam mencerdaskan kehidupan bangsa.

Karena AGI meniru kecerdasan manusia, pembahasan akan dimulai dengan fungsi otak manusia.

\section{FUNGSI OTAK MANUSIA}

Fungsi otak manusia dalam melaksanakan kecerdasannya bisa dikategorikan sebagai berikut (dengan istilah standar bahasa Inggris di dalam kurung): [1] [2] [3]

- Perencanaan dan pengendalian tindakan (action planning and control)

- Emosi (emotion)

- Kognisi (cognition):

- Persepsi (perception)

- Pikiran (thinking):

- Intuisi (intuition)

- Penalaran (reasoning)

- Komunikasi (communication), yaitu: menggunakan bahasa

- Pembelajaran (learning)

Ada pun fungsi otak lainnya yang tidak langsung berhubungan dengan kecerdasan adalah:

- Kesadaran fenomenal (phenomenal consciousness) atau kesadaran perasaan (feeling), disebut juga sebagai pengalaman subyektif (subjective experience) atau qualia $[4] \square[5] \square$

- Mimpi dan melamun

- Pengaturan organ-organ internal seperti jantung dan paru-paru

(C) Asosiasi Prakarsa Indonesia Cerdas (APIC) - 2018 
Hasil akhir (output) dari otak adalah keputusan, yang selanjutnya akan menjadi tindakan (action). Tindakan selalu dimaksudkan (intention) untuk memuaskan keinginan (desire).

Manusia selalu punya banyak keinginan, dan semua keinginan tersebut bersaing (competing desire). Emosi menentukan keinginan yang mana yang menjadi prioritas dengan cara memberikan nilai (value) untuk setiap keinginan tsb.

Kognisi adalah alat untuk mencapai keinginan, yang ditentukan oleh emosi. Jadi, dalam membuat model kecerdasan manusia, faktor emosi harus diperhitungkan.

Persepsi adalah pengenalan dari segala sesuatu yang diterima oleh panca indera. Ketika mata kita melihat kucing, kita mengenal (recognize) itu adalah kucing.

Secara proses, pikiran (thinking) dapat dibagi menjadi 2, yaitu: Intuisi (intuition) dan penalaran (reasoning). Riset yang paling mendalam tentang ini dilakukan oleh Daniel Kahneman hingga berhasil memenangkan Hadiah Nobel. Istilah yang digunakan Kahneman adalah System 1 (thinking fast) dan System 2 (thinking slow).[6] $\square$ Contoh berpikir intuisi adalah ketika grand master bermain catur secara simultan. Dalam hitungan detik, dengan menggunakan intuisinya, ia bisa memutuskan gerakan yang tepat. Sedangkan, contoh penalaran adalah logika deduktif.

Istilah-istilah lain yang sering digunakan untuk istilah pikiran adalah: intelek dan logika. Istilah lain dari penalaran adalah pikiran rasional (rational thinking). Kadang-kadang istilah logika diartikan sebagai penalaran. Ini kurang tepat, sebab intuisi pun menggunakan logika, yaitu: logika induktif. Yang membedakan penalaran dengan intuisi adalah penalaran dilakukan secara sadar (conscious) dan sengaja (deliberate).

Secara fungsional, pikiran meliputi antara lain: pemahaman (understanding), penyelesaian masalah (problem solving), perencanaan (planning), pengkhayalan (imagination), dan kreativitas (creativity). Ciri utama AGI bila dibandingkan dengan ANI (Artificial Narrow Intelligence) adalah memiliki kreativitas, dan seperti yang akan dijelaskan kemudian, kreativitas tidak mungkin muncul tanpa pemahaman.

\section{Masalah dan Prinsip}

Masalah dalam membuat AGI bisa dibagi menjadi 2 jenis:

\section{A. Perangkat Keras}

Otak manusia adalah hasil proses evolusi dari sistem syaraf hewan yang berisi sinyal listrik. Ini dimulai dari sinyal listrik hewan satu sel, lalu berevolusi selama 800 juta tahun sehingga akhirnya menjadi otak manusia. Situasinya sekarang adalah otak manusia berisi 100 miliar neuron, dan masing-masing neuron berhubungan dengan 1.000 neuron lainnya, sehingga total sambungannya bejumlah 100 triliun. Komputasi dilakukan di masing-masing sambungan ini. Bila sinyal neuron memiliki frekuensi $200 \mathrm{~Hz}$, maka komputasi yang dilakukan oleh otak adalah 20.000 triliun per detik.[7] $\square$ Pada saat ini hanya super komputer yang dapat menyamai kecepatan komputasi demikian tinggi. Namun, karena daya komputer meningkat terus secara eksponensial, suatu saat perangkat keras yang harganya cukup murah akan memiliki kecepatan komputasi setingkat dengan otak manusia. (Catatan: Angka-angka di atas bukanlah angka yang presisi melainkan hanya aproksimasi untuk menunjukkan besaran atau magnitudanya).

\section{B. Perangkat Lunak}

Masalah perangkat lunak lebih sulit daripada masalah perangkat lunak, sebab dari 100 triliun sambungan, setiap saat kira-kira 10 triliun sambungan mengalirkan sinyal listrik. Yang 
sangat rumit ditelaah adalah listrik ini mengalir dari mana ke mana, dan untuk apa. Sampai saat ini, tidak ada satu ahli pun yang mengetahui cara kerja otak secara lengkap.

Masalah perangkat lunak bisa dibedakan dari tingkat analisanya, dari tingkat tinggi sampai tingkat rendah, yaitu: tingkat sistem (yaitu: otak), subsistem, modul, submodul, komponen (yaitu: neuron), dan subkomponen. Makin tinggi tingkatnya, makin besar masalahnya, karena harus memperhatikan masalah-masalah di tingkat-tingkat yang lebih rendah. Masalahmasalah di tingkat rendah jumlahnya banyak sekali, namun relatif mudah dibandingkan dengan masalah di tingkat sistem.

Masalah utama dalam tingkat sistem dirumuskan oleh John Searle dalam CRA (Chinese Room Argument)[8], yang secara singkat adalah sebagai berikut:

Searle tidak mengerti bahasa Cina. Misalkan, dia diberi pertanyaan dalam bahasa Cina. Dia bisa saja menjawab pertanyaan itu dengan benar bila dia diberitahu aturan (rule) yang lengkap untuk menjawabnya. Lalu, walaupun jawabannya benar, apakah dia memahami jawaban yang disampaikannya? Tidak. Pertanyaannya pun dia tidak memahami. Itulah yang terjadi pada komputer.

Jadi, masalah utamanya adalah: Bagaimana caranya komputer memahami (understand) apa yang ada dalam pikiran manusia? Sampai sekarang tidak ada satu pun teknologi AI yang bisa memiliki pemahaman (understanding) seperti manusia. Sistem NLP (Natural Language Processing) seperti IBM Project Debater atau Google Duplex sangatlah mengesankan dala m melakukan tanya jawab, sehingga hampir tidak bisa dibedakan dengan manusia. Namun, kenyataannya, tidak ada sistem NLP yang memiliki pemahaman seperti manusia[9]. Misalnya, belum ada satu pun sistem yang lulus dari Turing Test.

Jadi, prinsip AGI yang pertama adalah: AGI harus memiliki pemahaman seperti manusia.

Para pendiri AI berpendapat bahwa, salah satu masalah paling besar dalam AI adalah bagaimana caranya komputer memahami bahasa manusia. John McCarthy menuliskan masalah ini dalam buku "Formalizing Common Sense"[10], dan Marvin Minsky menuliskannya dalam buku "The Society of Mind"[11] $\square$. Misalnya, Minsky mempertanyakan: bagaimana komputer bisa memahami birthday party? Birthday party adalah sebuah konsep yang terdiri dari 2 konsep: birthday dan party. Untuk memahami konsep birthday, komputer harus memahami konsep bahwa manusia itu ada di dunia karena dilahirkan oleh ibunya pada suatu hari. Lalu, apa artinya manusia? Dunia? Ibu? Hari? Kenapa Ibu bisa melahirkan? Semua itu merupakan konsep. Apa artinya party? party adalah sekumpulan manusia dengan sekumpulan makanan di suatu tempat yang mungkin didekorasi, dsb. Mau tidak mau, komputer harus memahami semua konsep itu untuk memahami birthday party.

Prinsip AGI yang kedua adalah: komputer bisa memiliki pemahaman dengan cara memproses konsep, dan sebuah konsep adalah agregasi dari banyak konsep lainnya. Dalam filsafat, ini disebut doktrin constructivist, yang dikemukakan oleh John Locke dalam bukunya "An Essay on Concerning Human Understanding"[12] $\square$. (Locke menggunakan istilah ide (idea), bukan konsep (concept), karena ide terdiri dari 2 jenis: konsep dan persep (percept)[13] $\square$. Namun, seperti yang akan dijelaskan kemudian, secara teknis konsep sama dengan persep, sehingga di sini akan digunakan istilah konsep.) Ada konsep yang sederhana. Ada konsep yang kompleks, yang terdiri dari konsep sederhana. Konsep yang paling sederhana disebut konsep atomistik, yaitu: konsep yang tidak bisa dipecah lagi. Konsep atomistik biasanya adalah persep, yaitu: konsep yang datang dari panca indera.

Berdasarkan prinsip ini, maka para ahli membuat sistem akuisisi pengetahuan (knowledge acquisition system). Misalnya, Cyc yang dikembangkan oleh Douglas Lenat sejak tahun 1984. Namun, sistem ini tidak punya pemahaman tentang pengetahuan seperti manusia karena ada

(C) Asosiasi Prakarsa Indonesia Cerdas (APIC) - 2018 
masalah SGP (Symbol Grounding Problem)[14] $\square$. Masalah ini muncul karena yang diproses hanya sebatas simbol; tidak ada pembumian (grounding), dengan kata lain: tidak ada isinya. Misalnya, konsep party dapat diuraikan sebagai sekumpulan manusia, dan manusia adalah sejenis hewan, lalu hewan adalah mahluk hidup, dan seterusnya. Bila penguraian konsep dilakukan hanya secara verbal, maka pasti tidak akan mencapai pemahaman yang lengkap seperti pemahaman oleh otak manusia, karena manusia mendapatkan informasi ini secara visual selain secara verbal.

Prinsip AGI yang ketiga adalah: Konsep tidak mungkin diuraikan hanya secara verbal menggunakan simbol.

Minsky sejak awal tidak percaya bahwa kecerdasan akan dicapai dengan cara memanipulasi simbol. Berbeda dengan John McCarthy, yang terus mengembangkan sistem pengolahan simbol, dan mengembangkan LISP sebagai bahasa pemrograman AI. Karena itu, timbul perpecahan antara Minsky dengan McCarthy, sehingga Minsky membuat laboratorium AI di MIT, sedangkan McCarthy di Stanford University. MIT kemudian mengembangkan teknologi yang kini dikenal sebagai ANN (Artificial Neural Network). (Minsky menciptakan Stochastic Neural Analog Reinforcement Calculator sebelum Rosenblatt membuat Perceptron.)

Setelah ANN dikembangkan menjadi PDP (Parallel Distributed Processing) di Carnegie Mellon University, terbukti bahwa ANN bisa menangani masalah-masalah kecerdasan yang tidak bisa ditangani oleh sistem pengolahan simbol, yaitu: pengenalan pola (pattern recognition) seperti otak manusia ketika melakukan persepsi. Dengan demikian, ANN memiliki kemampuan mengolah konsep sederhana, berupa persep. Namun, kemampuan ANN untuk mencapai kecerdasan manusia segera dipertanyakan oleh para ahli. Kritik yang paling komprehensif diutarakan oleh filsuf Fodor dan Pylyshyn[15] $\square$. Intinya adalah: ANN tidak mungkin bisa melakukan penalaran karena ANN tidak bisa melakukan pengolahan simbol, misalnya untuk pengolahan variabel dalam matematika atau kata ganti (pronoun) dalam bahasa.

Selama berpuluh-puluh tahun tidak pernah ada sistem ANN yang mampu melakukan penalaran, karena ANN tidak pernah mampu melakukan pengolahan simbol. Karena itu, sistem ANN seperti Leabra dari University of Colorado at Boulder akhirnya menggandeng ACT-R dari Carnegie Mellon University untuk melakukan pengolahan simbol, dan diberi nama SAL (Synthesis of ACT-R and Leabra). Sistem yang campuran (hybrid) seperti SAL hanya bisa melakukan pengolahan konsep di tingkat persepsi, karena penalarannya hanya melakukan pengolahan simbol. Namun, akhir-akhir ini DeepMind (anak perusahaan Google) berhasil menciptakan ANN yang dapat melakukan semacam penalaran yang disebut relation reasoning [16] $\square$.

Secara umum, AI terbagi menjadi 2 paradigma: symbol processing, dan connectionism (misalnya: ANN). Timbulnya 2 paradigma ini berhubungan erat dengan 2 fungsi utama kognisi, yaitu: penalaran dan persepsi. Prinsip AGI yang keempat adalah: AGI harus menyatukan (unify) 2 paradigma fungsi kognisi, yaitu: penalaran dan persepsi, dengan menggunakan teknologi yang sejenis.

Penulis mengusulkan sebuah model yang bisa menyelesaikan masalah-masalah utama di atas dengan menggunakan prinsip-prinsip AGI. Model ini dinamakan Model Kecerdasan Berbasis Konsep atau CBIM (Concept Based Intelligence Model). 


\section{Model: Diagram dan Algoritma}

Model CBIM akan dijelaskan dalam dua aspek:

- Secara statik menggunakan diagram

- Secara dinamik menggunakan algoritma

Baik diagram maupun algoritma bukanlah ide asli penulis. Diagram diambil dari ilmuwan neurosains, sedangkan algoritma yang akan digunakan berdasarkan algoritma yang sudah dikembangkan para ahli AI. Yang baru di sini adalah penggunaan algoritma tersebut untuk pengolahan konsep. Ini dalam teori evolusi disebut mekanisme eksaptasi (exaptation), yaitu: penggunaan organ yang sama untuk kebutuhan yang berbeda.

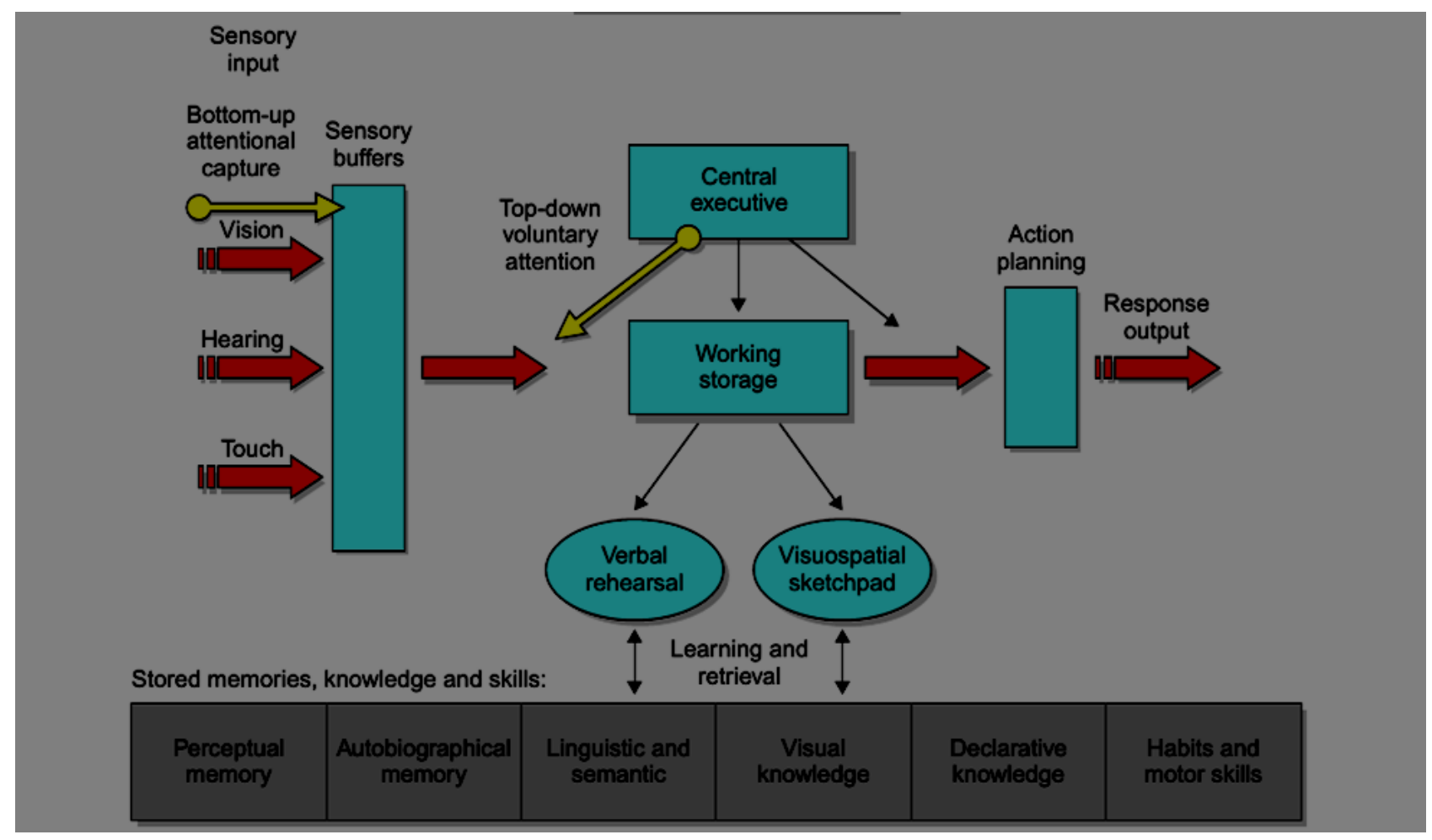

Gambar 1. Diagram Fungsi Otak 


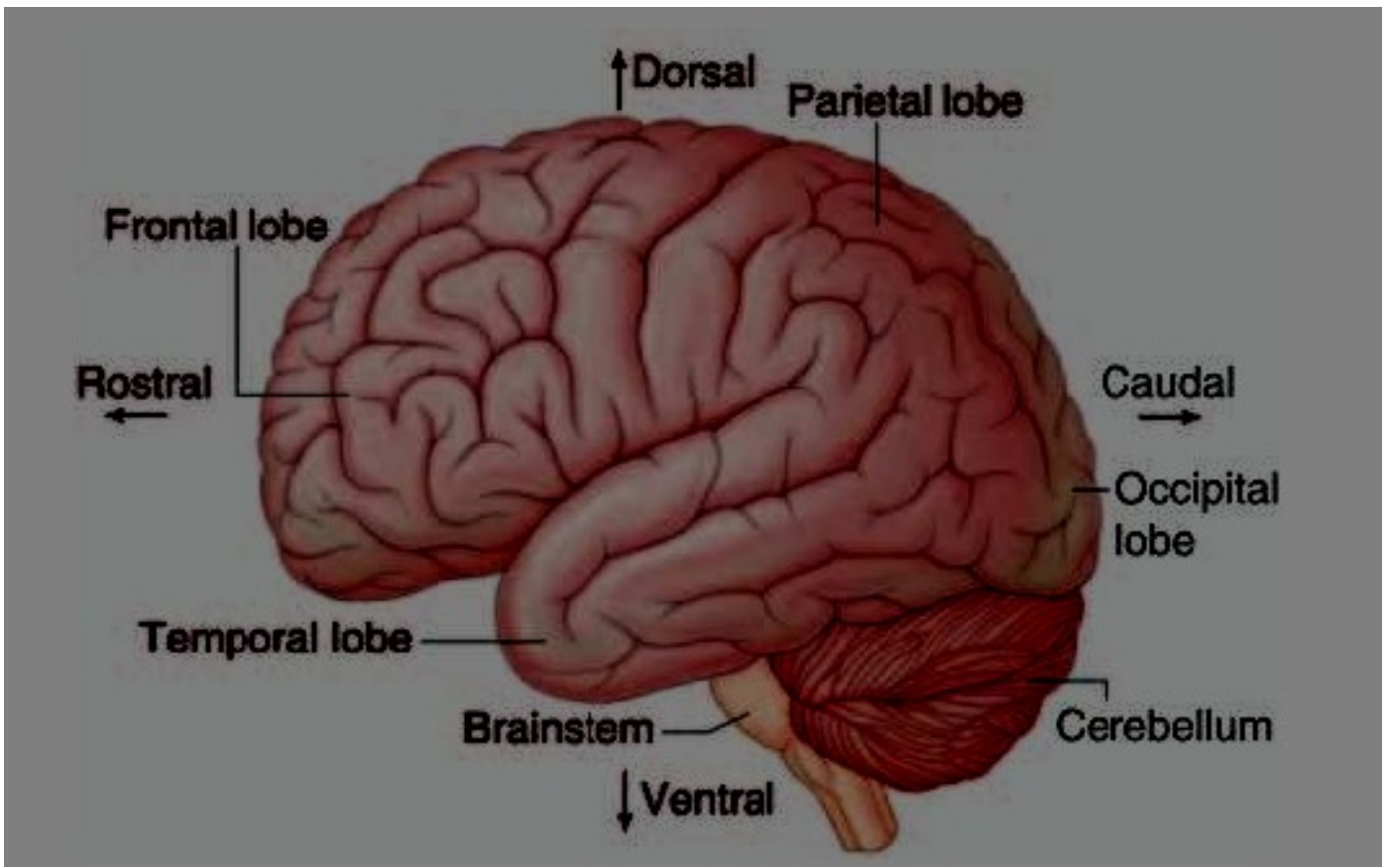

Gambar 2. Diagram Anatomi Otak

Gambar 1 menunjukkan fungsi otak [1] dalam tingkat yang lebih detail dari fungsi otak yang sudah dibahas sebelumnya. Gambar 2 menunjukkan anatomi otak [1] $\square$ secara sederhana.

Hubungan antara Gambar 1 dengan Gambar 2 adalah sebagai berikut: Sensory Buffers, WS (Working Storage), dan CE (Central Executive) letaknya di PFC (Pre Frontal Cortex), yaitu: Rostral Frontal Lobe di Gambar 2. WS (Working Storage) berisi VR (Verbal Rehearsal), dan VS (Visuospatial Sketchpad). CE letaknya lebih dorsal dari WS karena CE berfungsi sebagai eksekutif, yaitu: pengambilan keputusan untuk melakukan tindakan (decision for action). Action Planning letaknya di Frontal Lobe juga, lebih dorsal dari CE. Action Planning bersambungan langsung dengan neuron-neuron motorik, yang letaknya paling dorsal di Frontal Lobe. Jadi, fungsi otak secara keseluruhan adalah untuk melakukan tindakan (action).

Dengan diagram ini, kini akan dijelaskan algoritmanya, yaitu: bagaimana listrik mengalir di dalam otak. Dalam hal ini, kita akan menggunakan contoh yang konkrit, yaitu: bagaimana otak bisa memahami konsep birthday party ketika mendengar kata birthday party. Ada 2 tahap (stage) dan masing-masing tahap terdiri dari banyak putaran (cycle):

\section{A. Tahap 1: Persepsi}

Gelombang suara masuk ke telinga (Hearing dalam Gambar 1), diubah menjadi sinyal listrik, lalu melalui Sensory Buffers masuk ke WS (Working Storage). Kalau sinyal ini mendapatkan Attention dari CE (Central Executive), maka kita akan sadar (conscious) akan sinyal ini, lalu diproses secara sengaja (deliberate). Kalau tidak ada Attention, maka kita tidak sadar, dan sinyal ini akan diproses secara tidak sadar, atau tidak diproses.

Bagaimanakah sinyal yang ada di WS bisa dikenali sebagai kata birthday party? Caranya adalah dengan mengambil (retrieval dalam Gambar 1) informasi dari PM (Perceptual Memory) karena sebelumnya kata birthday party sudah pernah disimpan di PM. Kalau kata itu belum ada di PM, maka terjadi proses pembelajaran (learning). Dalam Gambar 1, ada dua anak panah yang berlawanan arah: retrieval dan learning. Keduanya dilakukan pada saat yang sama.

Pembelajaran terjadi karena otak menerima sinyal-sinyal yang sejenis berulang-ulang. Sinyalsinyal ini mengalami tiga macam transformasi:

(C)Asosiasi Prakarsa Indonesia Cerdas (APIC) - 2018 
- Pemetaan atau kategorisasi secara detail, yang terjadi di lapisan paling bawah dari WS dan PM. Dalam hal sinyal suara, ini terjadi di lapisan A1 (Auditory Layer 1), dimana sinyal dipetakan menjadi pola dengan fitur-fitur detail. Pola ini berupa penyalaan neuron sebanyak kira-kira 10\%. Misalnya A1 berisi 100 juta neuron, maka sebanyak 10 juta neuron akan menyala.

- Abstraksi atau kategorisasi secara hirarki, yang terjadi di lapisan memori yang lebih atas. Dalam hal sinyal suara, lapisan ini adalah A2 dan A3. Di lapisan-lapisan ini, kategorisasi dilakukan untuk mengambil fitur-fitur ringkasan atau abstrak dari lapisan di bawahnya, sehingga menghasilkan pola-pola (pattern) yang tersusun secara hirarki. Misalnya A2 berisi 20 juta neuron, maka sebanyak 2 juta neuron akan menyala.

- Penderetan atau pertautan secara temporal, dimana hasil kategorisasi di atas ditautkan secara temporal atau sekuensial.

Jadi, hasil dari pembelajaran adalah sebuah konsep, yang berupa sederetan pola penyalaan neuron. Dalam hal persepsi, hasil ini disebut persep (percept), yang disimpan di PM. Kalau PM diumpamakan sebagai pohon Natal, maka konsep (neuron-neuron yang nyala mati di PM) itu bagaikan lampu yang berkelap-kelip di pohon Natal.

Algoritma ini berdasarkan teori HTM (Hierachical Temporal Memory), yang dijelaskan oleh Jeff Hawkins dalam buku "On Intelligence"[17] $\square$. Kemudian, Hawkins mendirikan perusahaan Numenta dan membuat perangkat lunak open source NuPIC, yang berisi algoritma HTM.

Teori HTM merupakan teori yang sentral dalam model CBIM. Inti dari teori HTM adalah: semua informasi yang ada di dalam otak disimpan secara hirarki dan temporal (atau sekuensial); karena itu, otak bisa bisa melakukan prediksi. Selain Hawkins, Richard Granger pun yang mengemukakan algoritma seperti ini dalam makalah "Engines of the brain: The computational instruction set of human cognition" $[18] \square$.

Saat ini teknologi AI paling modern menggunakan algoritma seperti HTM, misalnya: Deep Reinforcement Learning yang digunakan dalam AlphaGo. Deep sama dengan Hierarchical [19] $\square$, sedangkan Reinforcement sama dengan Temporal[20] $\square$. Hanya saja algoritma modern memiliki kinerja yang jauh lebih unggul.

\section{B. Tahap 2: Pemahaman (Understanding)}

Bagaimanakah kata birthday party yang ada di WS (Working Storage) bisa dipahami sebagai konsep birthday party? Caranya adalah dengan mengambil (retrieval dalam Gambar 1) informasi dari DK (Declarative Knowledge) karena sebelumnya konsep birthday party sudah pernah disimpan di DK, misalnya: karena pernah diterangkan secara verbal.

Proses Pemahaman sama seperti proses Persepsi; bedanya adalah jenis memori yang digunakan: Untuk Pemahaman, memori yang digunakan adalah DK, sedangkan untuk Persepsi, memori yang digunakan adalah PM. Dengan demikian, algoritma untuk Pemahaman pun sama seperti algoritma untuk Persepsi, yaitu: algoritma HTM (Hierarchical Temporal Memory). Yang disimpan di Declarative Knowledge adalah konsep (concept), sedangkan yang disimpan di Perceptual Memory disebut persep (percept). Namun secara teknis, konsep dan persep adalah sama, yaitu: sederetan pola penyalaan neuron. (Dalam hal ini, pandangan John Locke sangatlah modern: ia menganggap persep sama dengan konsep.)

Sebuah konsep yang kompleks merupakan agregasi dari banyak sekali konsep-konsep yang lebih sederhana. Semua konsep yang lebih sederhana ini diambil (retrieval) dari Declarative Knowledge, atau dari memori lainnya ke WS melalui beberapa putaran (cycle). Makin kompleks konsepnya, makin banyak putarannya, dan makin besar kapasitas WS yang dibutuhkan.

Dalam hal kata birthday party, memori yang terlibat adalah:

- VK (Visual Knowledge). Ketika memahami birthday party, secara sadar atau tidak, manusia akan membayangkan secara visual sekumpulan orang dalam pesta ultah. 
Sesungguhnya, sebagian besar konsep akan memerlukan informasi dari VK. Karena itu, WS memiliki memori khusus untuk menangani VK, yang disebut Visuospatial Sketchpad dalam Gambar 1. Dengan demikian, simbol atau kata birthday party sekarang memperoleh pembumian (grounding).

- AM (Autobiographical Memory). Bila seseorang pernah ke birthday party, maka pengalaman ini disimpan di AM. Lalu, ketika ia mendengar kata birthday party, kemungkinan WS akan mengambil pengalaman ini dari AM.

- LS (Linguistic and Semantic). Sebetulnya antara tahap Persepsi dengan tahap Pemahaman terdapat 1 tahap perantara, yaitu: tahap Pengenalan Kata secara linguistik. Setelah suara ditransformasi menjadi kata di WS, kata menjadi kosa kata (vocabulary) yang punya semantik (ada artinya) karena WS mengambil (retrieval) informasi dari LS (Linguistic and Semantic). Kata birthday party dikenal dalam kosa kata karena sebelumnya kata tersebut disimpan dalam LS. Kosa kata dari LS ini merupakan simbol yang dipakai untuk mengambil konsep dari DK.

Dari penjelasan di atas, nyatalah bahwa konsep memiliki 2 karakteristik:

1. Konsep bisa diperbaharui. Sebagai contoh, seorang anak diceritakan mengenai birthday party, bahwa di situ ada banyak orang mengenakan pakaian bagus, ada musik dan minuman; tapi tidak diceritakan ada permainan. Anak ini akan menyimpan konsep ini dalam DK. Kemudian, ketika temannya membawa anak ini ke sebuah birthday party, ternyata ada permainan. Maka anak ini akan memperbaharui konsepnya tentang birthday party. Proses pembaharuan konsep ini disebut pembelajaran (learning).

2. Konsep biasanya tidak persis sama antara individu. Pembelajaran tergantung dari data yang masuk. Biasanya data yang masuk tidak persis sama ke setiap orang, sehingga konsep yang disimpan akan sedikit berbeda. Namun, makin banyak data yang masuk, abstrak yang dihasilkan dari kategorisasi secara hirarki makin sama antara individu.

Bila dibandingkan dengan algoritma Persepsi, algoritma Pemahaman lebih rumit dalam 2 hal:

- Deretan (sequence) penyalaan neuron dalam Persepsi biasanya pendek, sedangkan dalam Pemahaman bisa sangat panjang, terutama untuk konsep yang kompleks. Di dalam otak, hal ini ditangani oleh modul basal ganglia. Salah satu yang paling banyak melakukan penelitian dan simulasi basal ganglia dengan menggunakan ANN (Artificial Neural Network) adalah Randall O 'Reilly, dkk dari University of Colorado at Boulder.

- Persepsi hanya terjadi dalam satu modul memori, sedangkan Pemahaman melibatkan banyak modul memori. Dalam otak, ini diatur oleh modul thalamus yang letaknya tepat di tengah-tengah otak dan memiliki sambungan ke semua memori. Salah satu model kecerdasan yang paling lengkap (dan mencakup thalamus di dalamnya) adalah LIDA yang dikembangkan oleh Stan Franklin dari University of Memphis[21] $\square$. Namun, model ini menggunakan teknologi campuran (hybrid), sehingga ada kesenjangan antara persepsi, pemahaman dan penalaran.

Dalam psikologi, konsep merupakan topik yang penting. Karena itu, ada beberapa buku yang membahas khusus tentang konsep, misalnya "The Big Book of Concepts"[22] $\square$. Ada 3 teori tentang konsep yang tidak koheren, namun masing-masing teori memiliki bukti-bukti pendukung dari hasil eksperimen. Dengan menggunakan model CBIM, dapat dijelaskan bahwa ke 3 teori tersebut benar (valid):

1. Exemplar Theory mengatakan bahwa konsep diambil dari contoh. Teori ini valid karena konsep diambil dari hasil pemetaan.

2. Prototype Theory mengatakan bahwa konsep diambil dari fitur-fitur umum. Teori ini valid karena konsep diambil dari hasil abstraksi.

3. Knowledge Theory mengatakan bahwa konsep diambil dari hubungannya dengan konsep lain. Teori ini pun valid karena konsep merupakan bagian dari sederetan konsep lainnya.

(C) Asosiasi Prakarsa Indonesia Cerdas (APIC) - 2018 
Selanjutnya pada Bagian Kedua dari makalah ini akan dibahas bagaimana model CBIM dapat melakukan akuisisi pengetahuan seperti manusia, berkomunikasi menggunakan bahasa natural, melakukan penalaran, dan memunculkan kreatifitas.

\section{UCAPAN TERIMAKASIH}

Penulis mengucapkan terimakasih atas masukan dari Prof. Dr. Suhono H. Supangkat, Iwan Nadapdap, Dr. dr. Tauhid Nur Azhar, Alfred Boediman Ph.D., Widodo Susilo Wardoyo, T. Indra Kesuma, Hansen William.

\section{REFERENSI}

[1] B. J. Baars and N. M. Gage, Cognition, Brain, and Consciousness, 2nd ed. Elsevier Ltd., 2010.

[2] M. T. Banich and R. J. Compton, Cognitive Neuroscience, 4th ed. Cambridge University Press, 2018.

[3] M. W. Matlin, Cognition, 8th ed. Wiley, 2013.

[4] S. Blackmore, Conversations on consciousness: What the best minds think about the brain, free will, and what it means to be human. Oxford University Press, 2005.

[5] D. J. Chalmers, "Facing Up to the Problem of Consciousness," J. Conscious Stud., vol. 2, no. 3, pp. 200-219, 1995.

[6] D. Kahneman, Thinking, Fast and Slow. Farrar, Straus and Giroux, 2013.

[7] R. Kurzweil, The Age of Spiritual Machines. Viking Adult, 1999.

[8] J. Searle, "Minds, Brains, and Programs," Behav. Brain Sci., vol. 3, pp. 417-424, 1980.

[9] R. Aharonov, "IBM Debating Technologies: How Persuasive Can a Computer Be?," IBM Research Challenges of Science and Technology in the 21st Century, 2017. [Online]. Available: https://www.youtube.com/watch?v=1WQb2vdJ-KM.

[10] J. McCarthy, Formalizing Common Sense. Ablex, 1990.

[11] M. Minsky, The Society of Mind. Simon and Schuster, 1986.

[12] J. Locke, An Essay Concerning Human Understanding. Penguin Classics, 1690.

[13] E. J. Lowe, The Routledge Guidebook to Locke's Essay Concerning Human Understanding. Routledge, 2014.

[14] S. Harnad, "The Symbol Grounding Problem," Phys. D Nonlinear Phenom., vol. 42, pp. 335-346, 1990.

[15] J. Fodor and Z. Pylyshyn, "Connectionism and cognitive architecture: A critical analysis," Cognition, vol. 28, pp. 3-71, 1988.

[16] A. Santoro et al., "A simple neural network module for relational reasoning," pp. 1-16, 2017.

[17] J. Hawkins and S. Blakeslee, On Intelligence. St. Martin's Griffin, 2005.

[18] R. Granger, "Engines of the Brain Set of Human Cognition," AI Mag., vol. 32, pp. 15-32, 2006.

[19] Y. Bengio, "Learning Deep Architectures for AI," Found. Trends Mach. Learn., vol. 2, no. 1, pp. 1-127, 2009.

[20] F. Akhtar, Practical Reinforcement Learning: Develop self-evolving, intelligent agents with OpenAI Gym, Python and Java. Packt Publishing, 2017. 
[21] S. Franklin, S. Strain, J. Snaider, R. McCall, and U. Faghihi, "Global Workspace Theory, its LIDA model and the underlying neuroscience," Biol. Inspired Cogn. Archit., vol. 1, pp. 32-43, 2012.

[22] G. L. Murphy, The Big Book Of Concepts. The MIT Press, 2002. 